certain diseases, such as angina pectoris and cancer in various situations, and the risk of laryngeal involvement in smoking by tuberculous patients. General unanimity, however, seems to prevail as to the injurious effects of smoking by the young or by the subjects of cardiac neurosis or peptic ulcer.

\section{Food Preservation by Refrigeration}

THE publication, by the Australian Council for Scientific and Industrial Research, of a survey and scheme for research in refrigeration as applied to the preservation and transport of foodstuffs is a matter of importance at a time when attention is being focused on means of improving and extending export trade. The report has been prepared by Dr. J. R. Vickery, who is in charge of the newly created Section of Food Preservation. Information is particularly required as to the possibility of exporting beef in a chilled rather than frozen condition, and since there appears a considerable outlet in Great Britain for Australian bacon pigs, and good ham and bacon can be manufactured from frozen carcases, investigations are needed to determine the best methods of freezing, storing, and thawing them so that the curing process may be most successfully carried out. Fruit, particularly apples and pears, forms another large branch of Australia's export trade, but much loss is sustained annually through wastage during transport. Besides the need for more definite information as to the best type of storage conditions, knowledge is lacking as to where temperature and humidity are particularly important, and how far pre-picking factors such as orchard conditions and degree of maturity of the fruit, etc., may affect its subsequent storage life. The report concludes with recommendations for the establishment of two laboratories with attached cold storage facilities, at Brisbane and Melbourne, the former to study problems in meat export trade and in the transport of tropical fruits, and the latter to investigate the preservation and transport of non-tropical fruits.

\section{Estimation of Food in a Bird's Stomach}

THREe methods have been employed in estimating the quantity of food in a bird's stomach, in order to discover whether a bird is beneficial or harmful: the materials found may be weighed; they may be measured by volume; they may be counted. The weighing method is not practicable, because quantities are sometimes exceedingly small, and besides, relative weights of vegetable and insect matter convey no real information about the economic status of the bird. The second method, of estimating by volume beneficiál insects and injurious insects, useful vegetation and useless vegetation, has been almost universally adopted, following the practice of the experts in the Bureau of the Biological Survey of the United States Department of Agriculture. A reaction from this method is noticeable in a monograph on the foodhabits of the Californian brewer and red-winged blackbirds by Pablo S. Soriano (California Fish and Game, 1931 , p. 361). Here percentage by volume has been used only in estimating the space occupied by vege- table food or animal food or pebbles in the stomach, since the presence of one limits the presence of the others. But, since the degree of injury or benefit that an animal does depends directly upon the total number of injurious organisms that it destroys, the numerical method, of actually counting the specimens, has been followed in taking the percentage of the different kinds of foods. So an old method, once universally used, but ousted by the volumetric method, returns to favour again.

\section{Advancement of Science in Australasia}

THE twenty-first meeting of the Australian and New Zealand Association for the Advancement of Science is to be held in Sydney, during the week commencing Aug. 17. The president is Mr. E. C. Andrews, Government Geologist, Sydney, and the president-elect Sir Hubert Murray, LieutenantGovernor of Papua. According to the preliminary programme, the following presidents of sections have been appointed: Section A (Astronomy, Mathematics, and Physics), Prof. C. E. Weatherburn, University, Perth; Section B (Chemistry), Prof. L. S. Bagster, University, Brisbane; Section C (Geology), Prof. H. St. J. Summers, University, Melbourne; Section D (Zoology), Prof. G. E. Nicholls, University, Perth; Section F (Anthropology), Mr. E. W. P. Chinnery, Government Anthropologist, Rabaul, Mandated Territory of New Guinea ; Section G (Economics, Statistics, and Social Science), Mr. E. C. Dyason, 92 Queen Street, Melbourne; Section H (Engineering and Architecture), Mr. J. R. Kemp, Main Roads Commission, Brisbane ; Section I (Medical Science and National Health), Dr. R. W. Cilento, Director of Tropical Hygiene, Brisbane; Section K (Agriculture and Forestry), Prof. J. W. Paterson, University, Perth; Section L (Veterinary Science), Dr. W. A. Robertson, Director of the Division of Veterinary Hygiene, Department of Health, Canberra, F.C.T.; Section M (Botany), Dr. R. S. Rogers, 118 Hutt Street, Adelaide; Section $\mathrm{N}$ (Physiology and Experimental Biology), Dr. C. H. Kellaway, Director of the Walter and Eliza Hall Institute, Melbourne Hospital, Melbourne; Section P (Geography and Oceanography), Dr. P. Marshall, Department of Scientific and Industrial Research, Wellington, New Zealand. The honorary general secretary of the Association is Dr. A. B. Walkom, Science House, Sydney.

\section{$\mathrm{X}$-Ray Crystal Analysis and its Applications}

The discourse to be given by Sir William Bragg at the Royal Institution Conversazione on Friday evening, May 6, will be related to the various developments in pure and applied science which have depended on the use of the X-ray methods of analysing crystal structure. In order to supplement the discourse, which cannot refer to more than a few of the more important points, an exhibition is being arranged in the rooms of the Royal Institution which will demonstrate more fully the work that has been done. The contributors will be those who have carried on research work in this subject in various British labora- 